\title{
Socio-economic impact of the construction of an intermodal connection in Puerto Salgar, Cundinamarca
}

Impacto socio-económico de la construcción de una conexión intermodal en Puerto Salgar, Cundinamarca

DOI: https://doi.org/10.25043/19098642.172

Omar David Cruz Pineda ${ }^{1}$ Emmanuel Lara Abello ${ }^{2}$

\begin{abstract}
The aim of this work is to show the socio-economic impact in the Cundinamarca-Boyacá plateau produced by the construction and promotion of an alternative to relieve the freight transportation system in the region, and how it echoes in the manufacturing levels of the ship industry. For this reason, it is evaluated the option of establishing a logistics area in the town of Puerto Salgar (Cundinamarca) where may confluence an intermodal transportation system which emphasizes the Magdalena River as the main way for the country's development and Puerto Salgar as the main axis for the economic growth of the plateau. The Discrete Event Simulation (DES) methodology was used for this work, using information given by previous studies by the Ministerio de Transporte, the Dirección Nacional de Planeación and the Instituto Nacional de Vías; settting a conceptual model which determines and limit the study, and implementing a Rockwell Arena simulation.
\end{abstract}

Key words: Discrete Event Simulation, Magdalena River, Puerto Salgar, Cundinamarca-Boyacá plateau, logistics area.

\section{Resumen}

Este trabajo tiene como objetivo mostrar el impacto socio-económico en el altiplano cundiboyacense que sería producido por la construcción de una alternativa que permita aliviar el sistema de transporte de carga en la región, y su repercusión en los niveles de producción del sector astillero. Para esto se evalúa la opción de establecer un área logística en el municipio de Puerto Salgar (Cundinamarca) donde confluya un sistema intermodal de transporte que haga énfasis en el Río Magdalena como la vía principal para el desarrollo del país y Puerto Salgar como un eje del crecimiento económico del altiplano. Para esto se utilizó la metodología de Simulación de Eventos Discretos (SED), utilizando información suministrada por estudios anteriores del Ministerio de Transporte, la Dirección Nacional de Planeación, y el Instituto Nacional de Vías; estableciendo un modelo conceptual que determina y delimita el estudio propuesto, implementando una simulación en el software Rockwell Arena.

Palabras claves: Simulación de Eventos Discretos, Río Magdalena, Puerto Salgar, altiplano cundiboyacense, área logística.

Date Received: February $5^{\text {th }} 2017$ - Fecha de recepción: Febrero 5 de 2017

Date Accepted: March 10 2017 - Fecha de aceptación: Marzo 10 de 2017

\footnotetext{
${ }^{1}$ Student of Industrial Engineering. Universidad Nacional de Colombia Bogotá, Colombia. Email: odcruzp@unal.edu.co

${ }^{2}$ Student of Industrial Engineering. Universidad Nacional de Colombia Bogotá, Colombia. Email: emlaraab@unal.edu.co
} 


\section{Introduction}

The world economy, over the years, has experienced the effects produced by the phenomenon of globalization. Specifically, national and international markets have seen the emergence of new products, the development and evolution of some that already exist, and the failure of others, all as a result of the dynamics in the complex network of interactions present in the markets.

These effects have led to an increase in the demand for various products, at different scales, which has caused a greater flow of cargo transported all over the world.

The above has been visible in Colombia, where between 2008 and 2013 an annual average increase of $5.2 \%$ has been seen in domestic freight.

Of the entire freight moved in the country, about $18 \%$ is generated in the Cundinamarca-Boyacá plateau, where $25 \%$ of the population lives, representing $28.7 \%$ of national GDP (Ministry of Transport, 2011).

A range of policies has been developed which seek to meet the needs of the region in logistical matters through various alternatives. One of them, which has been widely studied and prioritized, is the development of an intermodal connection in Puerto Salgado, Cundinamarca, where the freight transport that is generated, and attracted to the Cundinamarca-Boyacá plateau, can converge.

This option is the basis of this work, which seeks to study the flow of cargo that this intermodal connection would have, its socio-economic effects in the area immediately adjacent to the project and its impact on the production levels of the shipyard sector in Colombia.

\section{Panorama of freight transport in Colombia}

\section{National level}

From 2002 to 2013, national freight transport has experienced linear growth attributed to the "dynamic domestic demand driven by household consumption, increased private sector investment and a stable international environment, but with a low-growth scenario" (Ministry of Transport, 2011). See Fig. $1{ }^{1}$

Fig. 1. National freight movement. (data in thousands of tons)

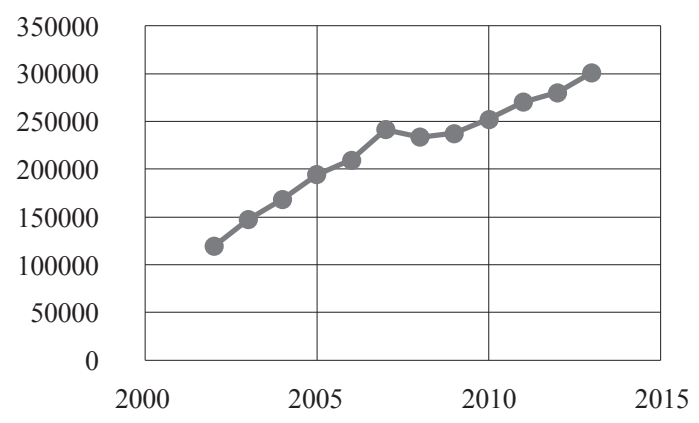

Cargo transport by land had the same behavior at the national level, representing on average $72 \%$ of the national total. See Fig. 2. ${ }^{2}$

Fig. 2. National cargo transport by land (data in thousands of tons)

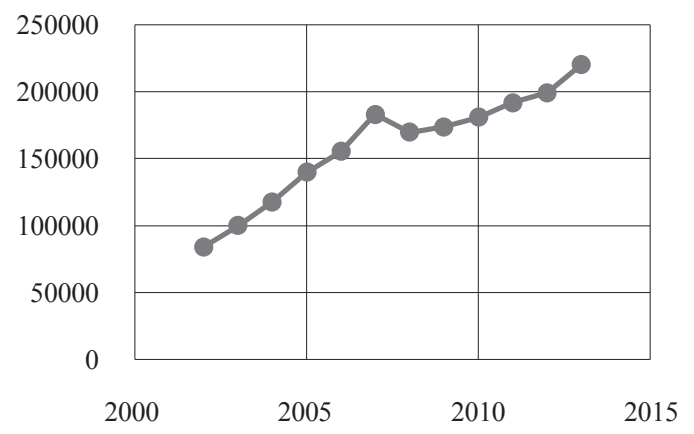

However, the same is not the case with fluvial transport, which displayed an irregular evolution, oscillating between $0.9 \%$ and $2.9 \%$ of the national freight transport. See Fig. 3. ${ }^{3}$

\footnotetext{
I Figure based on the data obtained by the "Transport in Figures Statistical Yearbook-Statistics 2015" of the Ministry of Transport. 2 Figure based on the data obtained by the "Transport in Figures Statistical Yearbook-Statistics 2015" of the Ministry of Transport. 3 Figure based on the data obtained by the "Transport in Figures Statistical Yearbook-Statistics 2015" of the Ministry of Transport.
} 
Fig. 3. National cargo transport by fluvial mode (data in thousands of tons)

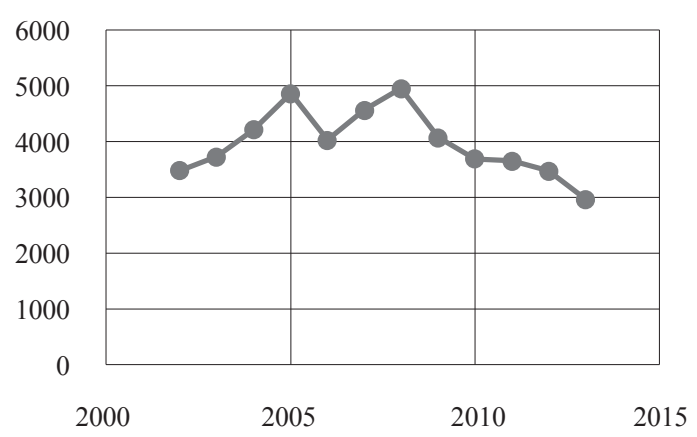

Other modes of transport managed in the country are the railway and the air, which will not be seen in this work.

\section{Plateau level}

With regard to cargo transport in the Cundinamarca-Boyacá plateau in 2010 it had $19.2 \%$ participation in the national freight trans'port. It is expected that by 2032 this share will have increased to $22.2 \%$ of a total of 629 million tons for the year. ${ }^{4}$

\section{Magdalena River Level}

Cargo transport in the Magdalena River has been in a decline since the of the last century to 2010, a product of the loss of navigability of the river in different sections. However, over recent years as a result of the CONPES 3758 document that proposes a plan for the recovery and management of the Magdalena River and an interest in promoting its use as a cargo transport corridor, it has seen an increase in freight movement. See Fig. $4 .^{5}$

Over the next few years, the goal is to gradually implement the alternative suggested by Hidroestudios S.A. for Comagdalena in 2002 for the reactivation of the navigability in the river, where the first phase in the first eight years seeks to revive the river ports of Barrancabermeja, Puerto

4 Source: Ministry of Transport, "Executive presentation PEIIT" (2011).

5 Figure based on the data obtained by the "Transport in Figures Statistical Yearbook -Statistics 2015" of the Ministry of Transport
Berrio and Puerto Salgar with a low investment and the second phase in the next twenty years with a high investment. Updating to 2017, the development of cargo transport by the River Magdalena would have this behavior. See Fig. 5. ${ }^{6}$

Fig. 4. Transport of cargo by the river Magdalena (data in tons)

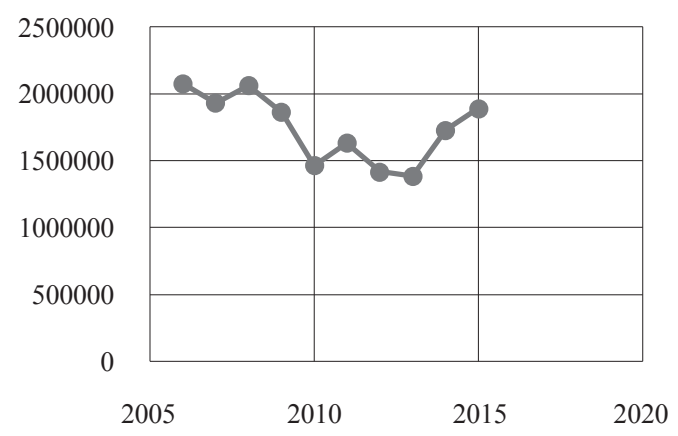

Fig. 5. Forecast for freight movement by the Magdalena River (2017-2045)

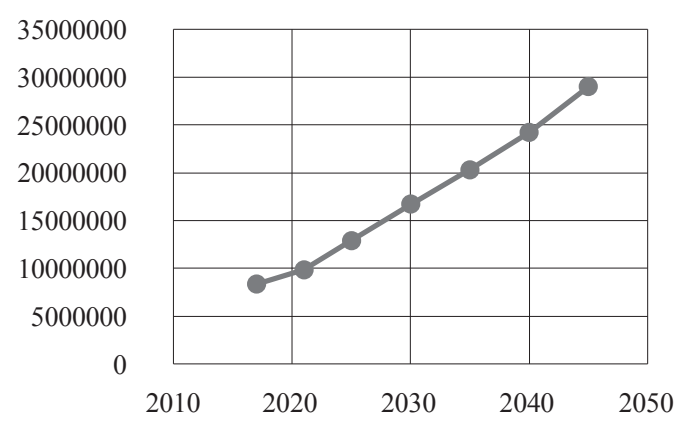

Puerto Salgar level

At present, there are no operations in the port of Puerto Salgar, although in 2014 a contract was awarded for the channeling and dredging of the river within a period of 13.5 years. ${ }^{7}$

At present, Puerto Salgar has a capacity as shown in Table $1 .^{8}$

\footnotetext{
Figure based on the data obtained from the "Demand study of Transport of the River System of Magdalena" by Cormagdalena (2002).

7 Source: http://www.eltiempo.com/colombia/otras-ciudades/ puerto-salgar-la-conexion-entre-el-caribe-y-bogota/14413898

Data obtained from the "Demand study of Transport of the River System of Magdalena" by Cormagdalena (2002)
} 
Table 1. Current Capacity of Puerto Salgar

\begin{tabular}{|c|c|}
\hline Port & Puerto Salgar \\
\hline \multicolumn{2}{|l|}{ Available Area $\mathrm{M}^{2}$} \\
\hline Container Yard & 8971 \\
\hline Warehouse & 2142 \\
\hline Loose Cargo Yard & 4800 \\
\hline General Load Capacity (Tons/Year) & 250,000 \\
\hline Containers (Teus/Year) & 6,250 \\
\hline Warehouse (Tons/Year) & 70,000 \\
\hline General Freight In Yard (Ton/Year) & 75,000 \\
\hline
\end{tabular}

As part of the alternative to reactivate the navigability of the Magdalena River, there is a forecast of the freight that Puerto Salgar would have. See Fig. 6.

Fig. 6. Forecast of freight in Puerto Salgar (2017-2045)

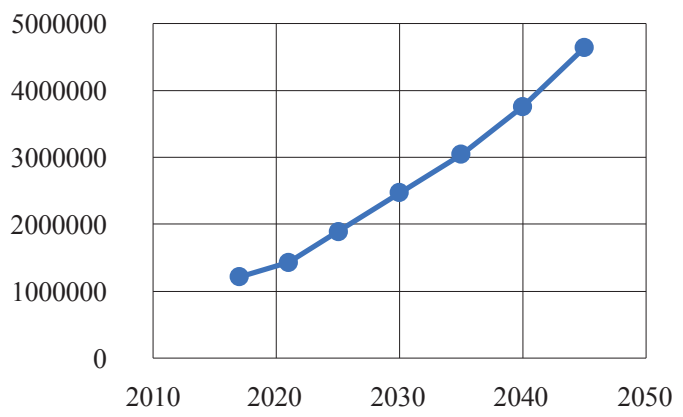

\section{Defining the problem}

The main objective of this work is the creation of a model that allows the transport of cargo produced in the Cundinamarca-Boyacá plateau to be simulated using an intermodal system in the municipality of Puerto Salgar.

With the model processing the most important expected results are the configuration of the fluvial fleet and the storage required to meet the demand for the transport of freight in an 8-year period for a set of sources, outputs and modes of pre-defined transport.

The facilities for the loading of trucks in the Plateau will not be subject to sizing, the same as the ground fleet required to transfer the cargo to the intermodal terminal.

The model will be used when monitoring the service level, so that the system resources have their capacities fixed to allow the entry and exit of cargo to service per year during the defined period of time.

In this order of ideas, the main procedure to solve this sizing problem will concentrate its efforts on identifying the capacity and quantity of minimum resources per year in order to guarantee the flow of cargo.

\section{Characterization of the system}

The proposed system will have the following structure. See Fig. 7.

Fig. 7. System Structure

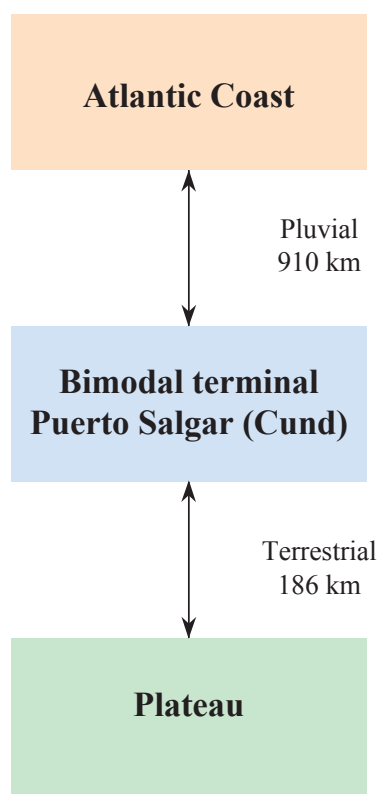

As shown in Fig. 7, the proposed system shall be composed of the following elements:

- 1 cargo flow center in the Plateau, which represents the entire cargo of the region leaving the intermodal terminal.

- 1 intermodal terminal

- 1 cargo flow center on the Atlantic coast, 
which represents all the cargo entering the intermodal terminal.

For this system the freight generated in the Plateau, mainly focused in the city of Bogotá, will be transported to the municipality of Puerto Salgar. These points of interest are located in the Department of Cundinamarca, as seen in Fig. 8.

Fig. 8. Location of the points of interest

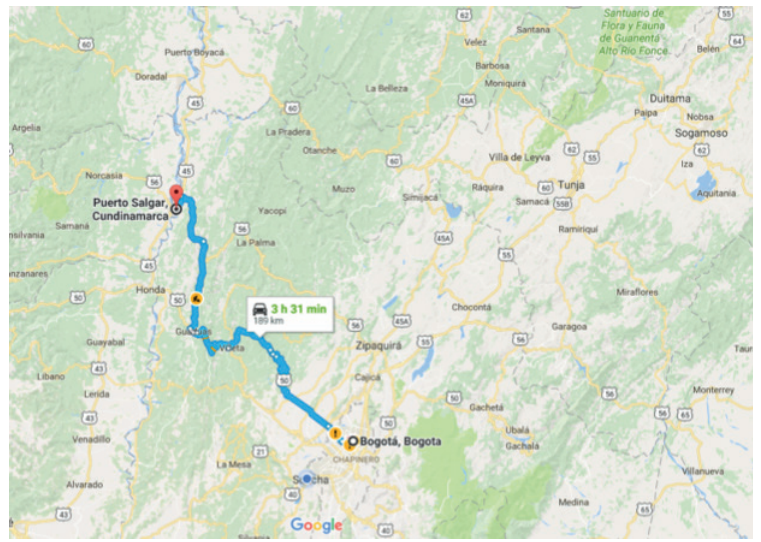

In the municipality of Puerto Salgar, the current port will be used for the construction of an intermodal terminal between the land and the fluvial mode.

The cargo will arrive at the aforementioned terminal and it will be stored in warehouses and then transferred to the river fleet that will then travel to an important port on the Atlantic coast, Barranquilla. See Fig. 9.

Fig. 9. Location of the points of interest

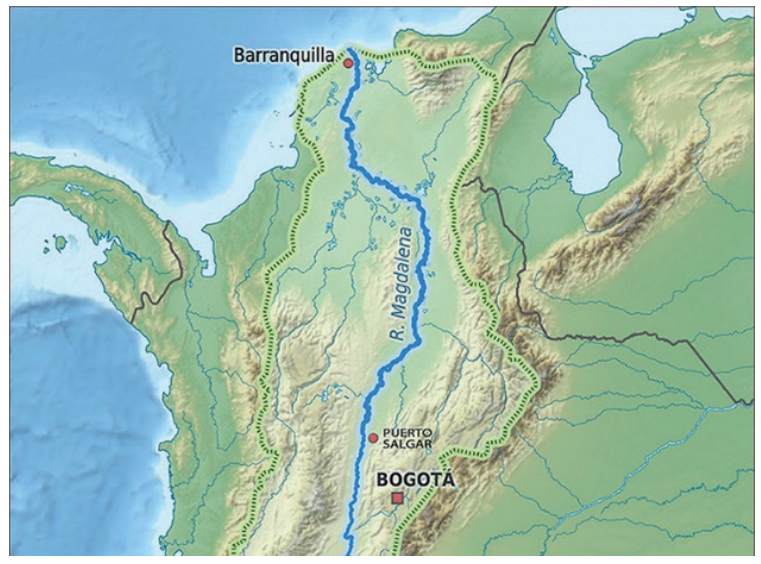

Considering the above description, the system will be characterized by the following subsystems:

\section{a. Ground Transportation Subsystem}

This subsystem will be composed of the road elements of the entire system, which is the only way to transport the freight generated or attracted by the Plateau towards the bimodal terminal of Puerto Salgar, where the cargo will be stored.

\section{b. Terminal Transshipment Subsystem}

The Puerto Salgar terminal will be modeled here, which will be the interface between the terrestrial and fluvial modes.

\section{c. River Transport Subsystem}

The seaport of Barranquilla will be linked to the intermodal terminal of Puerto Salgar through this system.

\section{d. Subsystem of loading and unloading in port}

Port operations will be the final subsystem of the proposed model.

\section{Simulation model and results}

Knowing the main problem and characterizing the system, a simulation model was created in Arena 14 to conduct experiments to dimension the proposed system.

It was necessary to define the main pattern scenario. This scenario is:

"Cargo transport between the port of Barranquilla and the Cundinamarca-Boyacá plateau, based on the forecast of demand expected for planning horizon of 8-years (2017 to 2025), through a type of intermodal system: land, from the main city of the Bogotá plateau to an intermodal terminal in Puerto Salgar (CUNDINAMARCA); fluvial, from the intermodal terminal of Puerto Salgar, sailing in the middle and lower areas of the river Magdalena to the port of Barranquilla (Atlántico department)."

Using the main scenario described above, a set of variables were determined within its range 
of values in order to test the combinations of variables looking for the best configuration that can dimensions the proposed system.

These variables were:

- Configuration of convoys.

- Storage capacity for the freight in the intermodal terminal.

- The following assumptions were considered:

- The main points of the system have warehouses to store the cargo and work 24 hours a day.

- The configuration of the convoys is one tug and two R2B2Bs, with a load capacity of 4800 tons.

- The depth of the river during the year varies between $3 \mathrm{ft}$ and $6 \mathrm{ft}$.

- The system must initially allow the entry of 1,211,860 thousand tons and the exit of $1,337,893$ tons.

- The system must finally allow the entry of $1,892,142$ tons and an output of 2,088,924 tons.

With these definitions the system simulation was performed for a period of 15 years and 5 replications.

After performing 10 simulation scenarios the following possible configurations were given for the terminal, which are presented in Table 2.

Table 2. Possible configurations based on simulation results

\begin{tabular}{rr}
\hline $\begin{array}{c}\text { River Fleet } \\
\text { (convoys) }\end{array}$ & \multicolumn{1}{c}{$\begin{array}{c}\text { Storage capacity } \\
\text { (ton/year) }\end{array}$} \\
\hline 10 & N/A \\
\hline 11 & N/A \\
\hline 12 & 340800 \\
\hline 13 & 168000 \\
\hline 14 & 100800 \\
\hline 15 & 52800 \\
\hline
\end{tabular}

From the previous results, the following fleet option is chosen as the best configuration:

- A total of 13 convoys at the end of the eight years.
- A final storage capacity of 168,000 tons/year, 23,000 ton/year above current capacity.

\section{Analysis of results}

\section{Economic Impact}

The economic impact of the construction of an intermodal platform in Puerto Salgar highlights the change in the modality of land-to-river transport due to a reduction of cost between 10\% and 50\% (Fedesarrollo, 2015) compared to the land transportation costs. This is due to the transport capacity of a convoy, at approximately 4,800 tons in Puerto Salgar.

Likewise, it increases the income that is perceived in the region. Taking into account that on average the flow of a TEU container would have a freight of about USD 76, and a TEU would have an average of 35 tons, and a convoy has capacity for 48,00 tons, an income is obtained from USD 2,631,467 in 2017 to USD 4.108.651 at 2025, a figure that would increase the value added in the region that was around the USD 55 million in 2013.

\section{Social Impact}

Mainly the construction of an intermodal platform will provide benefits for the generation of employment for the port population, many of them unskilled, and in addition, trainings could be offered by focusing on craft for barge management. These works will be produced by the operations of loading and unloading of trucks, storage in warehouses and patios, loading and unloading in barges, and all the administrative tasks that revolve around these activities.

\section{Impact on the shipyard sector}

At present, Puerto Salgar does not have barges for the mobilization of cargo. It is therefore necessary to buy or manufacture the 13 convoys mentioned, equivalent to 52 barges and 13 tugs. Of these, bearing in mind that law 1242 of 2008 establishes that river vessels must undergo a technical inspection every two years to keep their operating 
license, a potential market of 208 maintenances is projected over the 8 years of planning proposed in this work.

\section{Conclusions}

The construction of the intermodal connection in Puerto Salgar (Cundinamarca) will increase the levels of income of the region, as a result of the projected cargo flow, also the employment in the area will mainly benefit the population of the municipality by promoting unskilled jobs. Likewise, the cargo flows will increase and the logistic costs related to the use of ground transportation will be reduced.

The transport of fluvial cargo will provide relief to land transport, due to the great cargo capacity of cargo of this mode. As such it is necessary to have barges and tugs to meet thes proposed inputs and outputs in the simulation model, in order to guarantee the capacity and the flow of the cargo

Building an intermodal platform will not only have an effect on the economy of the region, it will also have an impact on the competitiveness and productivity of the commercial sector, directing river transport towards being an opportunity for the flow of the internal cargo of the country.

Through the efficient use of the means of transport, the productivity opportunities of the commercial sector provided by the construction of this platform can be leveraged.

\section{References}

GÓMES TORRES, ALBERTO. 2011. The shipyard sector in Colombia: a fluvial perspective. Faculty of Economy and business. University of Bolivar.

GÓMEZ TORRES, ALBERTO EMILIO. 2010. Strategic analysis of the shipyard Sector in Colombia: study from a Fluvial perspective Spanish. ResearchGate.com. DOI: 10.2139.

MARQUES, LUIS \& CANTILLO, VICTOR. 2011. Evaluation of the parameters of cost functions in the strategic cargo transport network for Colombia. Engineering and Development magazine. Vol. 29. ISSN: 01223461.

MURCIA, HENRY. 2015. A Bimodal Transportation Model for Steam Coal Exportation Based on Magdalena River as Main Waterway. University of São Paulo Department of Naval Architecture and Ocean Engineering.

NAVELENA. 2015. Recovery of the River Magdalena's navigability. 5th Solid Bulk Logistics Forum. Barranquilla.

NEDERLAND, ARCADIS \& JESYCA S.A.S. 2015. Fluvial Master Plan of Colombia 2015. Ministry of Transport. National Department of Planning. 